Brit. J. industr. Med., 1959, 16, 135.

\title{
A FOLLOW-UP STUDY OF MEN EXPOSED TO CADMIUM OXIDE FUME
}

\author{
BY \\ J. A. BONNELL, G. KAZANTZIS, and E. KING \\ From the Department for Research in Industrial Medicine (Medical Research Council), The London Hospital
}

(RECEIVED FOR PUBLICATION JUNE 30, 1958)

The results of a follow-up study of 100 men first examined in 1953 after exposure to cadmium oxide fume are presented and discussed.

In 1953 there were 19 cases of chronic cadmium poisoning amongst these men. Twenty-four new cases are now described. The first signs of chronic cadmium poisoning could be seen after a latent interval after exposure had ended. Respiratory function tests showed a greater deterioration in performance with increase in age in the exposed groups compared with the control group. The results in individual cases of clinical and radiological examination and of the respiratory function tests showed a deterioration in the condition of those men with emphysema in the original survey, and took place despite the fact that the majority of the men with chronic cadmium poisoning were not further exposed to cadmium after 1953. Eighteen of the 24 new cases had proteinuria only.

The evidence that chronic cadmium poisoning is associated with renal damage is discussed.

Chronic cadmium poisoning is an insidious disease associated with the development of emphysema and the excretion in the urine of a characteristic protein of low molecular weight. Emphysema and proteinuria may both be present or may occur separately in a particular case (Friberg, 1950; Bonnell, 1955).

In 1953 the health of 100 men exposed to cadmium fume during the manufacture of copper-cadmium alloys at two factories in England was investigated (Bonnell, 1955). As a result of that survey 19 cases of chronic cadmium poisoning were described amongst the men then at work, and four men who were so disabled by their symptoms as to be unable to work were examined in hospital, making a total of 23 cases. Of these 23 men, 11 had emphysema and proteinuria, eight had proteinuria alone, and four had emphysema alone. One man died in uraemia, the result of chronic renal failure.

Reports of further cases of proteinuria at one of these factories led us to undertake a follow-up study of the exposed men in 1957, four years after the original survey. It was hoped to obtain information about the course of the disease, particularly on whether it was self limiting in the absence of further exposure to cadmium, and whether the first symptoms or signs of poisoning could occur after a latent interval.

\section{Method of Investigation}

In order to preserve continuity with the initial investigation in 1953 the two factories will be referred to as Factory A and Factory B; the exposed groups at these factories, Group $1 \mathrm{~A}$ and Group $1 \mathrm{~B}$ respectively; and individual patients will again be referred to as Case $A(n)$ and Case $B(n)$. All the men comprising Groups $1 A$ and 1B who could be traced were asked to take part in the survey. Each man was interviewed and a clinical examination made. As in the previous survey the occupational history, past medical history, and family history were obtained, and specific enquiry was made about watery discharge from the nose, anosmia, yellow discoloration of the teeth, cough, dyspnoea, and frequency of micturition. At the clinical examination, blood pressure and chest expansion were measured. The haemoglobin concentration, erythrocyte sedimentation rate, haematocrit, and plasma proteins showed no abnormality in 1953 and these estimations were not repeated.

All the men provided early morning specimens of urine and additional specimens were obtained when the men attended for examination: 24-hour specimens were obtained from as many of the workmen as possible. The early morning specimens were tested for specific gravity, sugar, and blood, and all specimens were tested for protein. The methods used were $(a)$ the boiling test, (b) $25 \%$ trichloracetic acid, (c) $3 \%$ sulphosalicylic acid, and $(d)$ "altest" reagent tablets (supplied by Ames Co. Ltd.- active principle sulphosalicylic acid). Esbach's quantitative test was carried out on all urines giving positive results with any one test for protein. Two 
methods were used to test for glucose, one of which was a specific qualitative test and the other quantitative. Dipsticks ("clinistix", Ames Co. Ltd.), utilizing an enzymatic reaction, were used on all specimens of urine; a positive reaction is obtained at very high dilutions of glucose and the reaction is specific. All specimens in which a positive reaction was obtained by this method were then tested quantitatively by the "reagent tablet" ("clinitest", Ames Co. Ltd.). The cadmium concentration of each specimen of urine received was estimated by polarography.

The demonstration of protein in the urine is an objective test which can be confirmed by testing repeated specimens of urine. The presence of the characteristic protein in the urine is taken as sufficiént evidence for the diagnosis of chronic cadmium poisoning.

Respiratory function tests designed to show impairment of the ventilatory function of the lungs were performed by all the men who attended for examination. The following measurements were made: (a) Curves of expiratory fast vital capacity (forced expiratory spirogram, Gandevia and Hugh-Jones, 1957). Three curves were obtained from each subject and the mean time constant determined. (b) Maximum ventilatory capacity at 70 respirations per minute (M.V.C. ${ }_{70}$ ) (maximum voluntary ventilation 70, Gandevia and Hugh-Jones, 1957). Two estimations were made, and the mean value determined. (c) The swept fraction was determined by expressing the mean tidal excursion in the maximum ventilatory capacity test as a percentage of the vital capacity. $(d)$ The vital capacity was taken as the mean of the three expiratory fast vital capacity volumes.

The tests were again performed on the spirometer described by Bernstein, D'Silva, and Mendel (1952), and by the same operator as before. The details of the conduct of the tests and of the measurement of the tracings have already been described (D'Silva, Freeland, and Kazantzis, 1953; D'Silva and Kazantzis, 1954; Kazantzis, 1956).

A new control group was made up of the total complement of men working in the brass foundry in Factory $\mathbf{B}$. There were 63 men in this group. They gave occupational and past medical histories, and all performed the respiratory function tests. The original control groups could no longer be examined, as many of the men had found alternative employment since 1953. All the men seen on this occasion were asked to attend for chest radiographs. As on the previous visit to these factories two postero-anterior chest views were taken of each man, one in full inspiration and one in full expiration.

The chest radiographs were read by two observers who were not aware of the identity of the patient when the radiographs were viewed. The readings were repeated three times using the same technique as before. Thirtyfive of the 46 men examined at Factory $A$ and all 37 of the men examined at Factory $B$ attended for chest radiological examination. The radiological findings where relevant are included in the case notes (Appendix 1).

As in the previous investigation independent assessments of the respiratory system were made by clinical examination, radiological examination, and by tests of respiratory function. The diagnosis of emphysema was made by taking into consideration the clinical findings, the radiological findings, and the results of the respiratory function tests. Unless two of these three criteria were satisfied no man was regarded as suffering from emphysema.

The cadmium concentration of the atmosphere in the casting shops at both factories was estimated continuously over a period of five working days. Two methods were used. (a) For quantitative atmosphere sampling a benzamide pad (60 mesh), 1 inch in diameter and $10 \mathrm{~mm}$. in thickness was used as a collecting medium. An Edward's IV pump was used to draw the air through this pad at an air flow rate of 10 litres per minute. It has been our experience that the resistance of the benzamide pad at this rate of air flow is constant, enabling a flowcontrolling orifice to be inserted between the pad and the pump. Before reaching the benzamide pad the air passed through an elutriator of the type described by Wright (1954), but designed in this case to remove all the particles of cadmium oxide greater than $7 \mu$ in diameter. (b) In addition, a strip recorder was used to establish the times of greatest emission of cadmium oxide fume.

\section{Results}

In the two factories 83 of the 100 men who comprised Groups 1A and 1B were re-examined. In all, 24 new cases of chronic cadmium poisoning were discovered, five with emphysema and proteinuria, one with emphysema alone, and 18 with proteinuria alone. Thus of the 100 men first seen in 1953, a total of 43 are now known to have evidence of chronic cadmium poisoning. There were in addition four men whose case records were described by Bonnell (1955), namely, Cases A1, A2, A3, and A4, and two men formerly employed in Factory $A$ and seen for the first time in consultation with their family doctors in May, 1957 (Cases D1 and D2, Appendix 1).

Factory A.-Forty-six of the 58 men who comprised Group 1A attended for examination. Of the 12 absentees, four were known cases of chronic cadmium poisoning, Cases A6, A10, and A13, who were unable to travel to the factory because of severe dyspnoea, and Case A9 who had died of carcinoma of the bronchus. One man refused to attend for a further examination and seven had left the company's employ. Five of these were reported by their general practitioners to be in good health and two could not be traced.

Of the 46 men seen on this occasion in Group 1A, there were 19 cases of chronic cadmium poisoning; 14 were new cases (Table 1) of which five had emphysema and proteinuria, one had emphysema alone, and eight had proteinuria alone; five were old cases of which four had emphysema and proteinuria and one had proteinuria.

Of the 14 new cases, six were still employed in the 
TABLE 1

NEW CASES OF CADMIUM POISONING AT FACTORY A

\begin{tabular}{|c|c|c|c|c|c|c|c|c|c|c|c|c|c|}
\hline \multirow[b]{2}{*}{$\begin{array}{c}\text { Case } \\
\text { No. }\end{array}$} & \multirow[b]{2}{*}{ Age } & \multirow[b]{2}{*}{ Exposure } & \multirow[b]{2}{*}{ Symptoms } & \multirow[b]{2}{*}{$\begin{array}{l}\text { Clinical } \\
\text { Findings }\end{array}$} & \multirow[b]{2}{*}{$\underset{\text { (mg) }}{\text { B.P. }}$} & \multicolumn{2}{|r|}{ Urine } & \multicolumn{4}{|c|}{ Respiratory Function Tests } & \multirow[b]{2}{*}{$\begin{array}{l}\text { Chest } \\
\text { Radio- } \\
\text { graphs }\end{array}$} & \multirow[b]{2}{*}{ Diagnosis } \\
\hline & & & & & & Protein & $\underset{(\mu \mathrm{g} . / 1 .)}{\mathrm{Cd}}$ & $\begin{array}{l}\text { T.C. } \\
\text { (sec.) }\end{array}$ & $\begin{array}{l}\text { M.V.C. } \\
(1 . / \text { min. })\end{array}$ & $\underset{(\%)^{70}}{\text { S.F.7. }}$ & V.C. & & \\
\hline$\overline{\text { A } 24}$ & 62 & $\begin{array}{l}16 \text { years near } \\
\text { Cd furnace } \\
(1941-57)\end{array}$ & $\begin{array}{l}\text { Winter cough, } \\
\text { dyspnoea }\end{array}$ & Normal & $170 / 100$ & + ve & $\begin{array}{l}\text { Cd present } \\
\text { (not measur- } \\
\text { able) }\end{array}$ & $\begin{array}{c}0.96 \\
(0.75)^{*}\end{array}$ & $\begin{array}{c}145 \\
(141)\end{array}$ & $\begin{array}{c}43 \cdot 6 \\
(44 \cdot 3)\end{array}$ & $\begin{array}{c}4 \cdot 75 \\
(4 \cdot 53)\end{array}$ & Normal & Proteinuria \\
\hline A 17 & 64 & $\begin{array}{l}13 \text { years } \\
(1940-53)\end{array}$ & $\begin{array}{l}\text { Joint pain, } \\
\text { dyspnoea }\end{array}$ & $\begin{array}{l}\text { Rheumatoid } \\
\text { arthritis }\end{array}$ & $130 / 90$ & + ve & ${ }_{30}^{\text {abie) }}$ & $\begin{array}{c}1.16 \\
(0.94)\end{array}$ & 93 & $\begin{array}{l}35 \cdot 1 \\
(45)\end{array}$ & $\begin{array}{c}3.77 \\
(3.95)\end{array}$ & Emphysema & $\begin{array}{l}\text { Emphysema, } \\
\text { proteinuria }\end{array}$ \\
\hline A 25 & 52 & $\begin{array}{l}9 \text { years } \\
(1946-55)\end{array}$ & $\begin{array}{l}\text { Dyspnoea } 2 \\
\text { years, cough }\end{array}$ & Emphysema & $130 / 90$ & + ve & 30 & $\begin{array}{c}1.21 \\
(0.84)\end{array}$ & $\begin{array}{c}76 \\
(112)\end{array}$ & $\begin{array}{c}46 \cdot 2 \\
(43 \cdot 2)\end{array}$ & $\begin{array}{c}2 \cdot 34 \\
(3 \cdot 7)\end{array}$ & $\begin{array}{l}\text { Apical } \\
\text { bullae }\end{array}$ & $\begin{array}{l}\text { Emphysema, } \\
\text { proteinuria }\end{array}$ \\
\hline A 26 & 51 & $\begin{array}{l}21 \text { years near } \\
\text { Cd. furnace } \\
(1936-57)\end{array}$ & None & Normal & $160 / 70$ & + ve & 10 & $\begin{array}{c}0.62 \\
(0.45)\end{array}$ & $\begin{array}{l}173 \\
(145 \cdot 5)\end{array}$ & $\begin{array}{c}66 \\
(50)\end{array}$ & $\begin{array}{c}3 \cdot 75 \\
(4 \cdot 12)\end{array}$ & Normal & Proteinuria \\
\hline A 27 & 52 & $\begin{array}{l}10 \text { years } \\
(1947-57)\end{array}$ & None & Normal & $170 / 100$ & $+\mathrm{ve}$ & 10 & $\begin{array}{c}0.69 \\
(0.57)\end{array}$ & $\begin{array}{l}125 \\
(127)\end{array}$ & $\begin{array}{c}43 \\
(44)\end{array}$ & $\begin{array}{c}4 \cdot 18 \\
(4 \cdot 12)\end{array}$ & Normal & Proteinuria \\
\hline A 28 & 48 & $\begin{array}{l}13 \text { years } \\
(1944-57)\end{array}$ & $\begin{array}{l}\text { Dyspnoea on } \\
\text { effort; soreness } \\
\text { of nose with } \\
\text { occasional } \\
\text { epistaxis }\end{array}$ & Normal & $150 / 100$ & + ve & 60 & $\begin{array}{c}0.82 \\
(0.54)\end{array}$ & $\begin{array}{l}140 \\
(160)\end{array}$ & $\begin{array}{l}45 \\
(45)\end{array}$ & $\begin{array}{c}4.50 \\
(5 \cdot 09)\end{array}$ & Normal & Proteinuria \\
\hline A 29 & 59 & $\begin{array}{l}17 \text { years near } \\
\text { Cd furnace } \\
(1936-53)\end{array}$ & $\begin{array}{l}\text { Dyspnoea on } \\
\text { effort }\end{array}$ & $\begin{array}{l}\text { Obesity, } \\
\text { benign } \\
\text { hypertension }\end{array}$ & $210 / 100$ & $+\mathrm{ve}$ & $\begin{array}{l}\text { Cd present } \\
\text { (not measur- } \\
\text { able) }\end{array}$ & $\begin{array}{c}0.74 \\
(0.59)\end{array}$ & $\begin{array}{c}99 \\
(110 \cdot 4)\end{array}$ & $\begin{array}{c}41 \\
(40)\end{array}$ & $\begin{array}{c}3.45 \\
(3.95)\end{array}$ & Normal & Proteinuria \\
\hline A 30 & 61 & $\begin{array}{l}20 \text { years near } \\
\text { Cd furnace } \\
(1936-56)\end{array}$ & $\begin{array}{l}\text { Dyspnoea on } \\
\text { effort, pains }\end{array}$ & $\begin{array}{l}\text { Obesity, } \\
\text { osteoarthritis } \\
\text { lower limbs }\end{array}$ & $130 / 90$ & + ve & 18 & $\begin{array}{c}0.77 \\
(0.56)\end{array}$ & 125 & $45 \cdot 8$ & $\begin{array}{c}3 \cdot 90 \\
(3 \cdot 61)\end{array}$ & $\begin{array}{l}\text { Not } \\
\text { radio- } \\
\text { graphed }\end{array}$ & Proteinuria \\
\hline A 31 & 53 & $\begin{array}{l}21 \text { years } \\
(1936-57)\end{array}$ & $\begin{array}{l}\text { Dyspnoea on } \\
\text { effort }\end{array}$ & Emphysema & $140 / 90$ & + ve & 60 & $\begin{array}{c}1 \cdot 10 \\
(0.63)\end{array}$ & $\begin{array}{l}143.5 \\
(133 \cdot 3)\end{array}$ & $\begin{array}{c}51 \cdot 1 \\
(49 \cdot 1)\end{array}$ & $\begin{array}{l}4 \cdot 0 \\
(3 \cdot 88)\end{array}$ & Emphysema & $\begin{array}{l}\text { Emphysema, } \\
\text { proteinuria }\end{array}$ \\
\hline A 32 & 29 & $\begin{array}{l}9 \text { years near } \\
\text { Cd furnace } \\
(1942-53)\end{array}$ & None & Normal & $130 / 90$ & + ve & 10 & $\begin{array}{c}0.41 \\
(0.28)\end{array}$ & $\begin{array}{c}151.2 \\
(185 \cdot 6)\end{array}$ & $\begin{array}{c}55.5 \\
(69.0)\end{array}$ & $\begin{array}{c}3.89 \\
(3.84)\end{array}$ & Normal & Proteinuria \\
\hline A 33 & 51 & $\begin{array}{l}15 \text { years near } \\
\text { Cd furnace } \\
(1936-51)\end{array}$ & $\begin{array}{l}\text { Dyspnoea on } \\
\text { effort }\end{array}$ & $\begin{array}{l}\text { Obesity, } \\
\text { bronchospasm }\end{array}$ & $160 / 90$ & + ve & $\begin{array}{l}\text { No } \\
\text { cadmium }\end{array}$ & $\begin{array}{c}0.42 \\
(0.36)\end{array}$ & $\begin{array}{c}109 \cdot 5 \\
(113 \cdot 6)\end{array}$ & $\begin{array}{c}44 \cdot 4 \\
(45 \cdot 1)\end{array}$ & $\begin{array}{c}3 \cdot 53 \\
(3 \cdot 60)\end{array}$ & Normal & Proteinuria \\
\hline A 34 & 67 & $\begin{array}{l}20 \text { years near } \\
\text { Cd furnace } \\
(1936-56)\end{array}$ & $\begin{array}{l}\text { Cough with } \\
\text { sputum } 2 \text { years, } \\
\text { dyspnoea on } \\
\text { effort } 1 \text { year, } \\
\text { pain in joints } \\
3 \text { years }\end{array}$ & $\begin{array}{l}\text { Emphysema, } \\
\text { chronic } \\
\text { bronchitis }\end{array}$ & $160 / 90$ & + ve & 14 & $\begin{array}{c}1.30 \\
(0.83)\end{array}$ & $\begin{array}{c}44 \cdot 7 \\
(123 \cdot 5)\end{array}$ & $\begin{array}{c}17 \cdot 9 \\
(41 \cdot 0)\end{array}$ & $\begin{array}{c}3 \cdot 57 \\
(4 \cdot 30)\end{array}$ & $\begin{array}{l}\text { Not } \\
\text { radio- } \\
\text { graphed }\end{array}$ & $\begin{array}{l}\text { Emphysema, } \\
\text { proteinuria }\end{array}$ \\
\hline A 35 & 56 & $\begin{array}{l}35 \text { years } \\
(1920-55)\end{array}$ & $\begin{array}{l}\text { Dyspnoea and } \\
\text { cough }\end{array}$ & $\begin{array}{l}\text { Emphysema, } \\
\text { bronchitis }\end{array}$ & $150 / 100$ & + ve & 9 & $\begin{array}{c}1.21 \\
(0.68)\end{array}$ & $\begin{array}{c}81.0 \\
(125.9)\end{array}$ & $\begin{array}{l}28 \cdot 3 \\
(39 \cdot 5)\end{array}$ & $\begin{array}{c}4.09 \\
(4 \cdot 56)\end{array}$ & Normal & $\begin{array}{l}\text { Emphysema, } \\
\text { proteinuria }\end{array}$ \\
\hline A 36 & 46 & $\begin{array}{l}21 \text { years } \\
(1936-57)\end{array}$ & $\begin{array}{l}\text { Occasional } \\
\text { dyspnoea on } \\
\text { effort }\end{array}$ & $\begin{array}{l}\text { Emphysema, } \\
\text { bronchospasm }\end{array}$ & $110 / 80$ & Normal & $\begin{array}{l}\text { Cd present } \\
\text { (not measur- } \\
\text { able) }\end{array}$ & $\begin{array}{c}1 \cdot 28 \\
(0.83)\end{array}$ & $\begin{array}{c}95.6 \\
(118.6)\end{array}$ & $\begin{array}{c}35 \cdot 7 \\
(45 \cdot 6)\end{array}$ & $\begin{array}{c}3.82 \\
(3.71)\end{array}$ & Normal & Emphysema \\
\hline
\end{tabular}

*Figures in brackets refer to 1953 results.

casting shop, four on the copper-cadmium furnaces, and two in the vicinity casting brass and bronze; they had done this work for between 10 and 21 years. Eight had left the casting shop at some time between 1951 and 1956; their period of service in the casting shop varied between nine and 35 years. Two had retired (Cases A30 and A34), one because of arthritis and the other because of dyspnoea and arthritis; the remaining six worked in different departments in the factory, Case A17 because of rheumatoid arthritis and Case A35 because of cough and dyspnoea. All 14 of these men were normal at the time of the investigation in 1953. Four of these men (Cases A17, A29, A32, A33) had stopped working in the casting shop before that date so that they had not been further exposed to cadmium in the interim period.

At this factory nine cases of chronic cadmium poisoning were known to exist amongst the 58 men originally in the exposed group. There were in addition four men whose case records were summarized by Bonnell in 1955 (Cases A1, A2, A3, and A4).
Of these 13 men, Case A1 died from chronic renal failure (Bonnell, 1955), Case A4 died at home in 1955 of congestive cardiac failure as the result of emphysema, and Case A9 died at home in 1956 of bronchogenic carcinoma; unfortunately no necropsies were performed on the latter two cases. Cases A2 and A 3 were seen and in both the symptoms had become so severe that disability was complete; they were unable to leave their homes unless taken by motor car. On clinical examination both had severe emphysema, protein was present in the urine, and the respiratory function tests were grossly abnormal. Both men were excreting cadmium in the urine, Case A2, $60 \mu \mathrm{g}$. of cadmium per litre, Case A3, $36 \mu \mathrm{g}$. of cadmium per litre. Five of the remaining eight men were re-examined and the relevant follow-up notes are included in Appendix I.

The remaining three known cases of chronic cadmium poisoning were not examined, but it was ascertained from the general practitioners concerned that Cases A6 and A13 were severely disabled as the result of shortness of breath; Case A6 had 
TABLE 2

NEW CASES OF CADMIUM POISONING AT FACTORY B

\begin{tabular}{|c|c|c|c|c|c|c|c|c|c|c|c|c|c|}
\hline \multirow{2}{*}{$\begin{array}{c}\text { Case } \\
\text { No. }\end{array}$} & \multirow[b]{2}{*}{ Age } & \multirow{2}{*}{ Exposure } & \multirow[b]{2}{*}{ Symptoms } & \multirow{2}{*}{$\begin{array}{l}\text { Clinical } \\
\text { Findings }\end{array}$} & \multirow{2}{*}{$\begin{array}{l}\text { B.P. } \\
\text { (mm. }\end{array}$} & \multicolumn{2}{|c|}{ Urine } & \multicolumn{4}{|c|}{ Respiratory Function Tests } & \multirow{2}{*}{$\begin{array}{l}\text { Chest } \\
\text { Radio- } \\
\text { graphs }\end{array}$} & \multirow[b]{2}{*}{ Diagnosis } \\
\hline & & & & & & Protein & $\underset{(\mu \mathrm{g} . / 1 .)}{\mathrm{Cd}}$ & $\underset{\text { (sec.) }}{\text { T.C. }}$ & $\underset{(\mathrm{M} . \mathrm{min} .)}{\operatorname{M.C}}$ & $\begin{array}{l}\text { S.F } \\
(\%)\end{array}$ & $\begin{array}{l}\text { V.C. } \\
\text { (l.) }\end{array}$ & & \\
\hline$\overline{B 11}$ & 42 & $\begin{array}{l}18 \text { years } \\
(1939-57)\end{array}$ & $\begin{array}{l}\text { Dyspnoea } 3 \\
\text { years, cough } 3 \\
\text { years }\end{array}$ & Normal chest & $150 / 80$ & + ve & 28 & $\begin{array}{c}0.73 \\
(0.60) *\end{array}$ & $\begin{array}{c}84 \cdot 8 \\
(92 \cdot 6)\end{array}$ & $\begin{array}{c}26 \cdot 4 \\
(28 \cdot 5)\end{array}$ & $\begin{array}{c}4 \cdot 58 \\
(4 \cdot 62)\end{array}$ & Normal & Proteinuria \\
\hline B 16 & 50 & $\begin{array}{l}5 \text { years } \\
(1945-50)\end{array}$ & $\begin{array}{l}\text { Chronic nasal } \\
\text { discharge }\end{array}$ & & $130 / 90$ & $+\mathbf{v e}$ & 46 & $\begin{array}{c}0.55 \\
(0.43)\end{array}$ & $\begin{array}{c}181 \cdot 3 \\
(195 \cdot 9)\end{array}$ & $\begin{array}{c}59 \cdot 2 \\
(60 \cdot 0)\end{array}$ & $\begin{array}{c}4 \cdot 37 \\
(4 \cdot 66)\end{array}$ & Normal & Proteinuria \\
\hline B 17 & 44 & $\begin{array}{l}18 \text { years } \\
\text { (1939-57) } \\
\text { Crane driver: } \\
\text { situated over } \\
\text { CuCd furnaces }\end{array}$ & None & Normal chest & $140 / 90$ & $+\mathrm{ve}$ & No Cd & $\begin{array}{l}160 \cdot 4 \\
(0 \cdot 63)\end{array}$ & $\begin{array}{c}160 \cdot 4 \\
(205 \cdot 0)\end{array}$ & $\begin{array}{c}39.8 \\
(53.3)\end{array}$ & $\begin{array}{c}5 \cdot 57 \\
(5 \cdot 52)\end{array}$ & Normal & Proteinuria \\
\hline B 18 & 41 & $\begin{array}{l}7 \text { years } \\
\text { (between } \\
1935-45 \text { ) }\end{array}$ & None & $\begin{array}{l}\text { Refused } \\
\text { clinical } \\
\text { examination }\end{array}$ & - & $+\mathbf{v e}$ & No Cd & $\begin{array}{c}0.55 \\
(0 \cdot 40)\end{array}$ & $\begin{array}{c}165 \cdot 8 \\
(189 \cdot 0)\end{array}$ & $\begin{array}{c}62 \cdot 3 \\
(62 \cdot 7)\end{array}$ & $\begin{array}{c}3 \cdot 80 \\
(4 \cdot 30)\end{array}$ & Normal & Proteinuria \\
\hline B 33 & 62 & $\begin{array}{l}7 \text { years } \\
(1940-47)\end{array}$ & $\begin{array}{l}\text { Cough, sputum, } \\
\text { dyspnoea } 3 \\
\text { years }\end{array}$ & $\begin{array}{l}\text { Chronic } \\
\text { bronchitis }\end{array}$ & $160 / 90$ & + ve & No Cd & $\begin{array}{c}0.71 \\
(0.48)\end{array}$ & $\begin{array}{c}61 \cdot 7 \\
(106 \cdot 5)\end{array}$ & $\begin{array}{c}35.6 \\
(52.9)\end{array}$ & $\begin{array}{c}2.48 \\
(2 \cdot 88)\end{array}$ & Normal & Proteinuria \\
\hline В 19 & 49 & $\begin{array}{l}16 \text { years } \\
(1941-57)\end{array}$ & None & Normal & $140 / 90$ & + ve & 40 & $\begin{array}{c}0.48 \\
(0.45)\end{array}$ & $\begin{array}{c}150 \cdot 4 \\
(149 \cdot 7)\end{array}$ & $\begin{array}{c}57 \cdot 4 \\
(53 \cdot 2)\end{array}$ & $\begin{array}{c}3 \cdot 75 \\
(4 \cdot 02)\end{array}$ & Normal & Proteinuria \\
\hline B 31 & 64 & $\begin{array}{l}14 \text { years } \\
\text { (1936-50) } \\
\text { (intermittent) }\end{array}$ & $\begin{array}{l}\text { Dyspnoea on } \\
\text { effort } 6 \text { years }\end{array}$ & $\begin{array}{l}\text { Very small } \\
\text { man, other- } \\
\text { wise ncrmal } \\
\text { chest }\end{array}$ & $190 / 100$ & $+\mathbf{v e}$ & 38 & $\begin{array}{c}0.39 \\
(0 \cdot 34)\end{array}$ & $\begin{array}{c}92 \cdot 6 \\
(97 \cdot 2)\end{array}$ & $\begin{array}{c}81 \cdot 1 \\
(51 \cdot 2)\end{array}$ & $\begin{array}{c}1 \cdot 63 \\
(2 \cdot 70)\end{array}$ & Normal & Proteinuria \\
\hline B 20 & 53 & $\begin{array}{l}11 \text { years } \\
(1946-57)\end{array}$ & $\begin{array}{l}\text { Dyspnoea on } \\
\text { effort } 4 \text { years, } \\
\text { cough } 6 \text { years }\end{array}$ & Normal chest & $130 / 90$ & + ve & 110 & $\begin{array}{c}0 \cdot 74 \\
(0 \cdot 54)\end{array}$ & $\begin{array}{c}100 \cdot 3 \\
(119 \cdot 6)\end{array}$ & $\begin{array}{c}44 \cdot 8 \\
(48 \cdot 6)\end{array}$ & $\begin{array}{c}3 \cdot 20 \\
(3 \cdot 50)\end{array}$ & Normal & Proteinuria \\
\hline B 21 & 47 & $\begin{array}{l}5 \text { years } \\
\text { (between } \\
1940-47 \text { ) }\end{array}$ & $\begin{array}{l}\text { Dyspnoea on } \\
\text { effort } 3 \text { years, } \\
\text { cough } 2 \text { years }\end{array}$ & Normal chest & $130 / 80$ & + ve & $\begin{array}{l}\text { Cd present } \\
\text { (not measur- } \\
\text { able) }\end{array}$ & $\begin{array}{c}1.08 \\
(0.96)\end{array}$ & $\begin{array}{c}96 \cdot 4 \\
(120 \cdot 3)\end{array}$ & $\begin{array}{c}32 \cdot 6 \\
(37 \cdot 1)\end{array}$ & $\begin{array}{c}4 \cdot 22 \\
(4 \cdot 62)\end{array}$ & Normal & Proteinuria \\
\hline B 22 & 52 & $\begin{array}{l}3 \text { years } \\
(1939-42)\end{array}$ & Symptom free & $\begin{array}{l}\text { (Information } \\
\text { gained from } \\
\text { family doctor) }\end{array}$ & & + ve & $\begin{array}{l}\text { Cd present } \\
\text { (not measur- } \\
\text { able) }\end{array}$ & - & - & - & - & - & Proteinuria \\
\hline
\end{tabular}

*Figures in brackets refer to 1953 results.

emphysema and congestive cardiac failure and Case A13 had emphysema. A specimen of urine from the former was now shown to contain protein. Case A10 was able to continue at work.

In the previous investigation (King, 1955) atmospheric samples were taken from two positions in the casting shop, one near the pit furnace where the master alloy was manufactured, position $A$, and one near the rocker furnace, position $B$. On this occasion all samples were taken from position B only. Samples were taken on nine consecutive periods of 12 hours each in order to estimate the average concentration during this time. On no occasion did the concentration of cadmium in the atmosphere exceed $37 \mu \mathrm{g} . / \mathrm{m}^{3}$ for any one nine-hour period and the average concentration for the week was $13 \mu \mathrm{g} . / \mathrm{m}^{3}$. The results compare favourably with those reported in 1953 when the range of atmosphere concentration was 13 to $89 \mu \mathrm{g} . / \mathrm{m}^{3}$ in 12 -hour periods. The better conditions had been achieved by improved exhaust ventilation over the rocker furnace. The trace obtained on the strip recorder suggested that part at least of the general concentration of cadmium in the atmosphere was due to occasional bad positioning of the exhaust hood by a particular furnace man.

Factory B.--Thirty-seven of the 42 men originally in Group 1B attended for examination. Of the five absentees one man known to have chronic cadmium posioning had died (Case B3). The other four were traced through their general practitioners; three were in apparent good health and one was found to have the characteristic proteinuria. Of the 37 men seen at the factory, 18 showed signs of chronic cadmium poisoning. There are therefore 19 cases to be discussed. Of these, 10 were new cases all with proteinuria (Table 2) and nine were old cases, four with emphysema and proteinuria, four with proteinuria alone, and one with emphysema alone.

Of the 10 new cases, four continued to work on the copper-cadmium furnaces; they had done this work for between 11 and 18 years. The other six had not been exposed to cadmium in their work for at least seven years. These 10 men were examined in 1953 and found to be quite normal.

In addition, three men who had been shown to have proteinuria on one occasion by Kench and Smith (1957) provided repeated specimens of urine but the proteinuria could not be demonstrated unequivocally. Quantitative protein estimation by the Biuret method was carried out on one occasion and the protein content varied between 3.5 and 5.5 $\mathrm{mg}$. total protein per $100 \mathrm{ml}$. of urine. It is possible that the proteinuria is transient when it first appears. Should that be so, careful observation and repeated testing of the urine would show the onset of persistent proteinuria in these cases.

At this factory 10 cases of chronic cadmium 
poisoning were known to exist amongst the 42 men originally in the exposed group (Group 1B, Bonnell, 1955). The findings at that time were summarized in table form and the case history of one man who was severely disabled (Case B1) was described in full, Of these 10 men, one (Case B3) had died of acute bronchopneumonia and the post-mortem findings have been reported by Kench and Smith (1957). The remaining nine men were re-examined in the present investigation and the relevant follow-up notes are included in Appendix 1.

Master Alloy Manufacture.-The master alloy (50/50 copper-cadmium) was manufactured in a separate building from the main casting shop where the low percentage $(1 \%)$ copper-cadmium alloys were cast. Atmospheric samples were taken in both workshops.

A direct comparison with conditions existing at the time of the previous investigation (King, 1955) was impossible owing to improvements in the exhaust system and pouring technique. The atmospheric samples were taken at a position nearer to the furnacemen than on the previous occasion. For a period of 10 hours of master alloy casting the average concentration of cadmium was $30 \mu \mathrm{g}$. $/ \mathrm{m}^{3}$. During the process of mixing and pouring, the furnacemen wore Siebe Gorman microfilter dust respirators, the efficiency of which is discussed in Appendix 2.

Final Alloy Manufacture.-Atmospheric samples were taken at two positions comparable to points $F$ and $G$ in the previous investigation for eight consecutive 12-hour periods. The results are summarized in Table 3.

TABLE 3

RESULTS OF ATMOSPHERE SAMPLING AT FACTORY B

\begin{tabular}{cl} 
Position F & $\begin{array}{l}\text { Range } 18-80 \mu \mathrm{g} . \mathrm{Cd} / \mathrm{m}^{3}\left(29-270 \mu \mathrm{gg} . \mathrm{Cd} /{ }^{3}\right) \\
\text { Average } 46 \mu \mathrm{g} \mathrm{Cd} / \mathrm{m}^{3}\left(106 \mu \mathrm{gg} / \mathrm{m}^{3}\right)\end{array}$ \\
Position G & $\begin{array}{l}\text { Range } 10-41 \mu \mathrm{gg} . \mathrm{Cd} / \mathrm{m}^{3}\left(5-56 \mu \mathrm{\mu g} . / \mathrm{m}^{3}\right) \\
\text { Average } 20 \mu \mathrm{g} . \mathrm{Cd} / \mathrm{m}^{3}\left(38 \mu \mathrm{g} . / \mathrm{m}^{3}\right)\end{array}$ \\
\hline
\end{tabular}

Figures in brackets refer to previous report (King, 1955).

These data suggest that the working conditions have improved since the earlier survey. At that time additional amounts of cadmium could have been absorbed by the workman as the result of working close to the furnaces during mixing and pouring operations. In 1957 Siebe Gorman microfilter respirators were worn by the furnacemen during these operations and the atmospheric concentrations probably represent maximum exposure.

Cadmium Content of Respirator Pads.-The exposure of the men to cadmium fume depended to a great extent on their care when working near the source of the fume... The working technique and the variable nature of the fume emission caused serious difficulties when attempting to assess accurately the degree of exposure of an individual workman. This problem was reduced by the use of efficient dust respirators, but the cadmium content of the filter pads after use gave a measure of the possible exposure of an individual under the conditions observed at this factory.

The filter pads from the respirators used by the furnacemen during each casting operation were collected and their cadmium content estimated (Table 4).

TABLE 4

CADMIUM CONTENT OF FILTER PADS OF RESPIRATORS

\begin{tabular}{l|c|c}
\hline & $\begin{array}{c}\text { Master Alloy } \\
\text { Casting }\end{array}$ & $\begin{array}{c}\text { Final Alloy } \\
\text { Casting }\end{array}$ \\
\cline { 1 - 2 } & $\begin{array}{c}12 \text { filters obtained } \\
\text { from }\end{array}$ & $\begin{array}{c}\text { 20 filters obtained } \\
\text { from } \\
\text { workmen }\end{array}$ \\
\hline $\begin{array}{l}\text { Average time of use } \\
\text { Average cadmium content } \\
\text { Range of cadmium content }\end{array}$ & $\begin{array}{c}0.14 \mathrm{~min} . \\
0.05-0.31 \mathrm{mg} .\end{array}$ & $\begin{array}{c}20 \mathrm{~min} . \\
0.5 \mathrm{mg} .\end{array}$ \\
\hline
\end{tabular}

In this series three of the four highest values were from the pads supplied by one workman (Case B20). It is interesting to note that this man's urinary excretion of cadmium was far higher than that of any of his workmates (Table 2).

These data give the total cadmium content of the air inhaled by the workmen concerned, and include the large non-respirable particles of cadmium oxide or particles of mixed oxides from sparks. They do, however, demonstrate the possible variation in exposure of workmen performing essentially the same work under the same conditions.

\section{Results of Respiratory Function Tests}

The number of men examined on this occasion and the mean ages of the groups are shown in Table 5. The table also shows the mean values in the three groups for vital capacity, maximum ventilatory capacity, swept fraction, and time constant of the expiratory fast vital capacity curve. The corresponding mean values obtained four years ago are also shown for comparison. In the exposed groups, the mean values for 1957 were lower than the corresponding values for 1953 for vital capacity, swept fraction, and maximum ventilatory capacity, and higher for time constant. This suggested deterioration in respiratory function. However, the effect of age and the incidence of respiratory disease in the population from which these samples were drawn must be taken into account before any conclusions are drawn as to the effects of exposure to cadmium fume. 
TABLE 5

MEAN VALUES AND STANDARD DEVIATIONS FOR THE CONTROL AND EXPOSED GROUPS IN EACH FACTORY

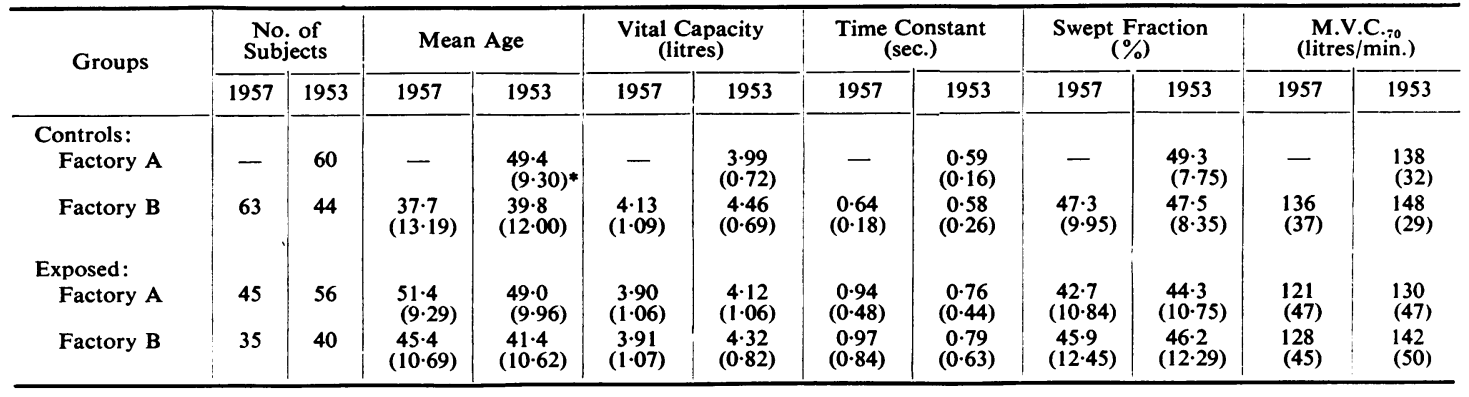

*Standard deviations are in brackets.

TABLE 6

REGRESSIONS ON AGE FOR VITAL CAPACITY, TIME CONSTANT, SWEPT FRACTION, AND MAXIMUM VENTILATORY CAPACITY IN CONTROL AND EXPOSED GROUPS OF BOTH FACTORIES, WITH A COMPARISON BETWEEN SLOPES OF REGRESSION LINES

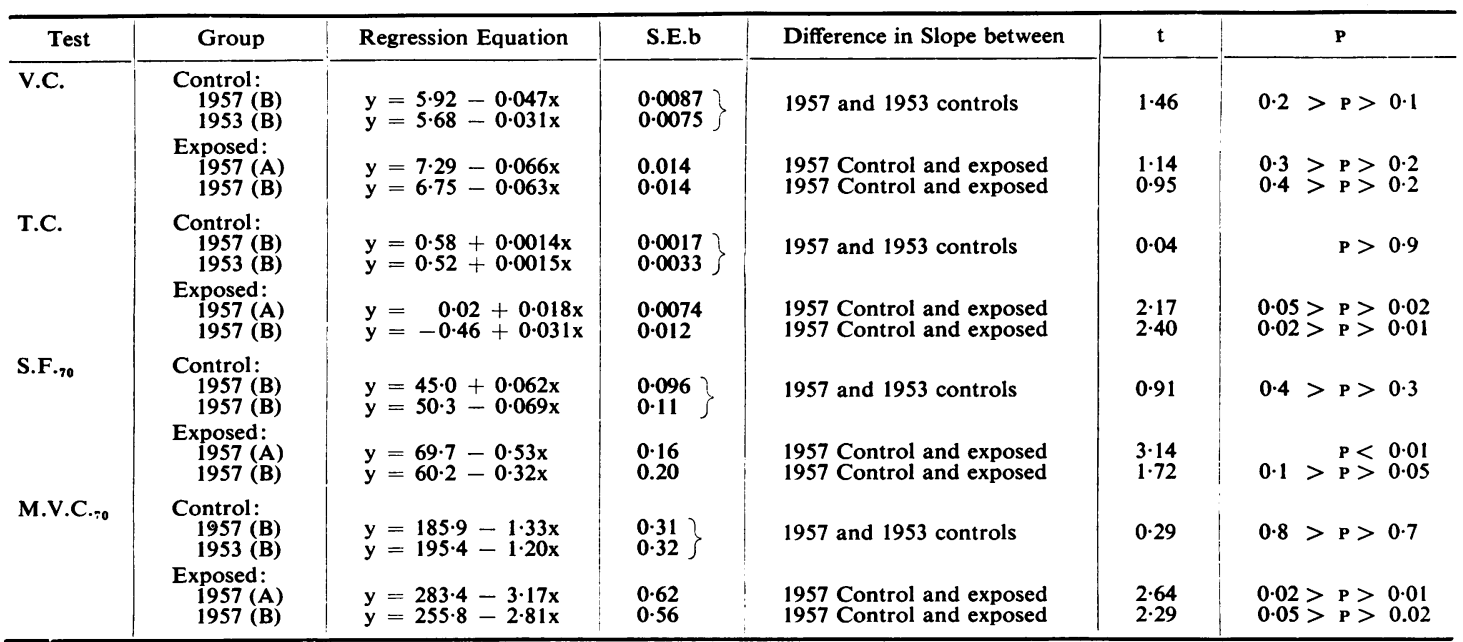

Comparison of Control Groups in 1953 and 1957.The regression on age was calculated for each of the variables measured in the present control group. It was ascertained that this relationship could be assumed to be linear over the age-range studied (Armitage, 1955). These regression equations are shown in Table 6. The regression lines obtained were then compared for both slope and position with the corresponding regression lines obtained in the 1953 control group in Factory B.

No significant differences were shown to exist between these two control groups in the slope of the regression lines for time constant, M.V.C., vital capacity, or swept fraction (Table 6). For the time constant, the results in the two control groups were close, there being no significant difference in slope or in position of the two regression lines (Fig. 1). For the vital capacity and M.V.C., the regression on age was similar in the two groups but the distance apart of the regression lines was significant, the 1957 values being lower than the 1953 values.

Comparison between Present Control and Exposed Groups.-This comparison was effected by the same technique of fitting linear regression lines to the available data. The regression equations obtained for the exposed groups in both factories are shown in Table 6.

Significant differences between the control and exposed groups were obtained for time constant, swept fraction, and maximum ventilatory capacity. It can be seen that in the exposed groups the maximum ventilatory capacity decreased at a greater rate with increase in age, and the time constant of the expiratory fast vital capacity curve increased at a greater rate with age. The regression lines representing 
Fig. 1.- Regression of time constant on age in the control and exposed groups of both factories.

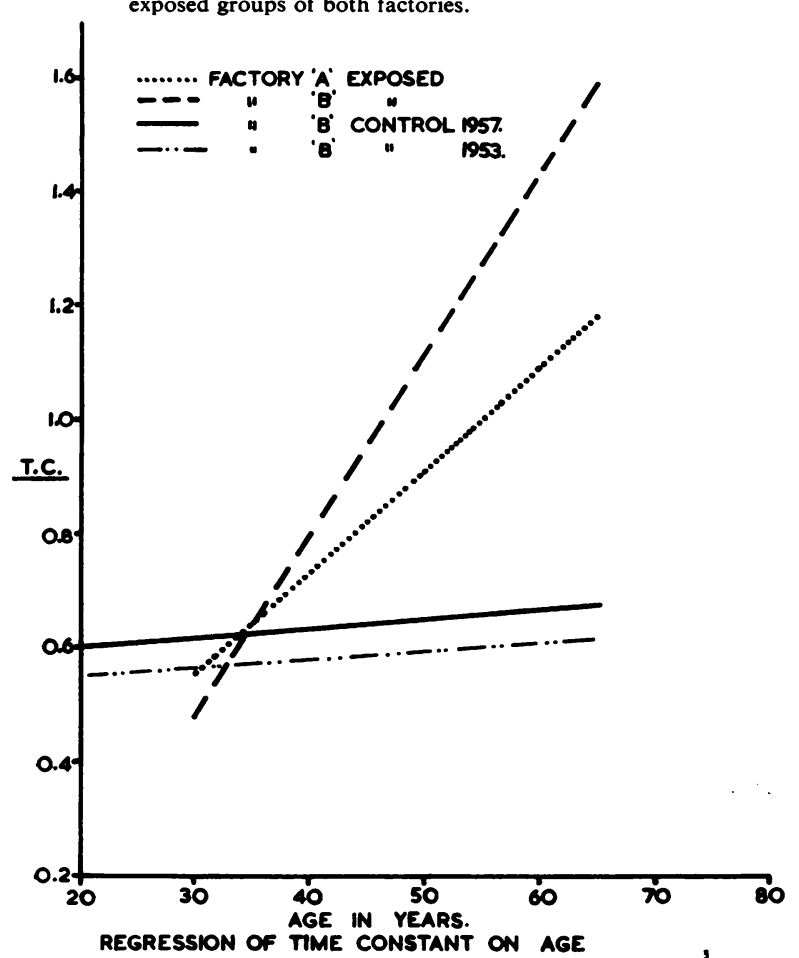

REGRESSION OF TIME CONSTANT ON AGE

these equations for the time constant in the control and exposed groups are shown diagrammatically in Fig. 1. The swept fractions were also found to decrease at a greater rate in the exposed groups with increase in age, although the difference between the exposed group in Factory $B$ and the control group does not reach the $5 \%$ level of significance. No significant difference could be found between the control and exposed groups in the rate at which the vital capacity decrease with increase in age.

Comparison between 1953 and 1957 Exposed Groups.-Fig. 2 shows the individual values for time constant for 1957 plotted against the respective values for 1953. The majority of values for time constant were higher in 1957, suggesting a deterioration of respiratory function. In the absence of a follow-up study of the original control group it was difficult to attribute the deterioration in respiratory function to factors other than the increase in age and the expected incidence of respiratory disease in the population from which this sample was drawn.

The expected change in each of the tests over a period of four years was calculated from the regression equations based on the present controls. The difference between the 1957 and 1953 performance of the exposed group was adjusted by this amount, so that any residual difference could be attributed to some factor other than the expected deterioration due to increase in age. These residual differences were tested to see whether they were significantly different from zero, allowance having been made for the scatter of the observations about the regression line of the control subjects. For time constant these residual differences were highly significant; they were also significantly different from zero for the M.V.C., suggesting that the deterioration in these quantities over four years was greater than could be expected on the basis of age alone. For vital capacity and swept fraction, the residual differences were not significantly different from zero (Table 7). For the purposes of this analysis, only those subjects working at the time of the survey were included in the exposed

Fig. 2.-Comparison of individual time constants in 1953 and 1957 in the exposed groups of both factories.

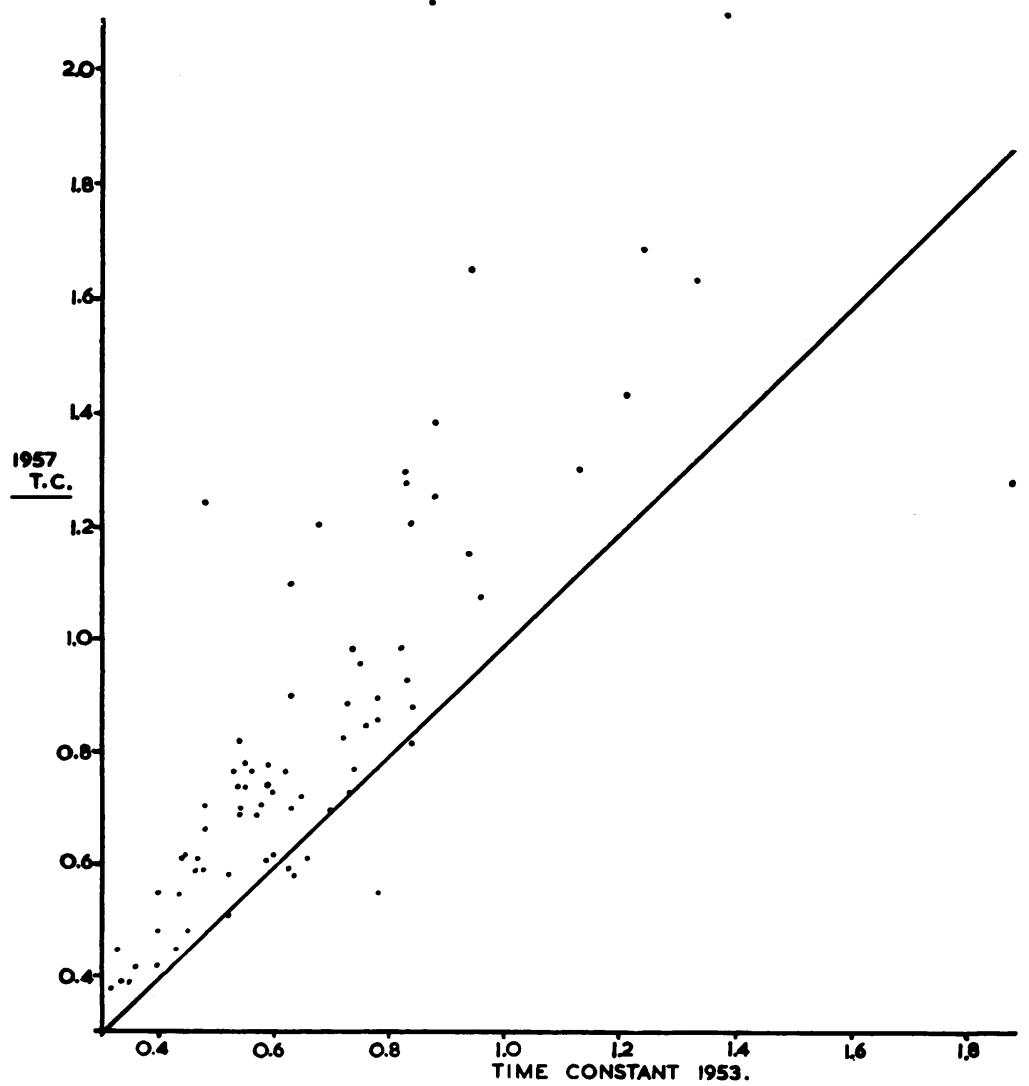


TABLE 7

SIGNIFICANCE OF MEAN DIFFERENCES BETWEEN 1953 AND 1957 RESULTS

\begin{tabular}{l|c|c|c}
\hline \multicolumn{1}{c|}{ Test } & $\begin{array}{c}\text { Mean Residual } \\
\text { Difference }\end{array}$ & $t$ & \multicolumn{1}{|c}{$\mathbf{P}$} \\
\hline V.C. & +0.126 & 1.0 & $0.4>P>0.3$ \\
T.C. & +0.181 & 5.0 & $0.0<P<0.001$ \\
S.F. & +2.16 & 1.4 & $0.2>P>0.1$ \\
M.V.C. & +11.18 & 2.5 & $0.02>P>0.01$ \\
\hline
\end{tabular}

group. In this way the control and exposed groups were made comparable. The significant differences shown in Table 7 were obtained despite the fact that the results of the men not at work, i.e., the most severely affected members of the exposed group, were not included.

From these results, it was concluded that the deterioration in performance over four years was significantly greater than could be expected from the behaviour of the control group studied.

Individual Performances.-In the initial investigation four years ago limits of normality for swept fraction and time constant were defined, which were based on the performance of the control group in each factory. Men with a swept fraction less than twice the standard deviation from the mean or a time constant greater than twice the standard deviation from the mean were selected for comparison with clinical and radiological findings. In the present investigation the same values for the limits of normality were adopted in order that results might be compared.

Of the 21 men who gave abnormal results in 1953, two have died (A4, B3) and have been considered elsewhere in this paper. Four men from Factory A had left the company's employ and were not reexamined (A10, A13, A14, A18). It was ascertained that two of these men were suffering from shortness of breath. The remaining 15 men again had values for swept fraction or time constant outside the described limits. These values are shown in Table 8.

In the 1957 survey an additional 11 men had abnormal respiratory function tests; in four men both the swept fraction and the time constant were abnormal, in six men only the time constant and in one man only the swept fraction were abnormal (Table 8). Of the 10 men whose time constants were greater than two standard deviations from the mean for the first time in 1957, there were seven whose time constants fell between one and two standard deviations from the mean in 1953.

\section{Results of Examination of Urine}

Nine of the 46 men in Factory A were found to give a consistently positive test for glucose in the urine. Ten of the 37 men in Factory B gave positive
TABLE 8

SWEPT FRACTIONS AND TIME CONSTANTS FALLING OUTSIDE TWICE THE STANDARD DEVIATION OF THE MEAN FOR CONTROL GROUP IN FACTORIES A AND B

\begin{tabular}{|c|c|c|c|}
\hline Case No. & Age & $\begin{array}{c}\text { T.C. } \\
>0.91 \text { sec. }\end{array}$ & $\underset{<34 \%^{*}}{\text { S.F }}$ \\
\hline $\begin{array}{l}\text { A2 } \\
\text { A3 } \\
\text { A5 } \\
\text { A8 } \\
\text { A11 } \\
\text { A12 } \\
\text { A15 } \\
\text { A16 } \\
\text { A17 } \\
\text { A20 } \\
\text { A24 } \\
\text { A25 } \\
\text { A31 } \\
\text { A34 } \\
\text { A35 } \\
\text { A36 } \\
\text { A37 } \\
\text { A38 } \\
\text { A39 } \\
\text { A40 }\end{array}$ & $\begin{array}{l}56 \\
62 \\
62 \\
59 \\
69 \\
58 \\
49 \\
54 \\
64 \\
44 \\
62 \\
52 \\
53 \\
67 \\
56 \\
46 \\
34 \\
47 \\
56 \\
60\end{array}$ & $\begin{array}{l}2.59 \\
3.05 \\
1.28 \\
1.44 \\
2.12 \\
2.95 \\
1.69 \\
1.31 \\
1.16 \\
1.26 \\
0.96 \\
1.21 \\
1.10 \\
1.30 \\
1.21 \\
1.28 \\
1.39 \\
1.25 \\
0.93 \\
-\end{array}$ & $\begin{array}{c}22 \cdot 4 \\
22 \cdot 2 \\
\text { Did not perform } \\
33 \cdot 0 \\
28 \cdot 7 \\
15 \cdot 2 \\
29 \cdot 3 \\
= \\
= \\
= \\
17 \cdot 9 \\
28 \cdot 3 \\
3 \overline{-} \\
\overline{=} \\
27 \cdot 3\end{array}$ \\
\hline $\begin{array}{l}\text { B1 } \\
\text { B2 } \\
\text { B4 } \\
\text { B5 } \\
\text { B6 } \\
\text { B11 }\end{array}$ & $\begin{array}{l}56 \\
53 \\
61 \\
63 \\
54 \\
42\end{array}$ & $\begin{array}{l}4 \cdot 55 \\
1.64 \\
2 \cdot 10 \\
2 \cdot 17 \\
3 \cdot 15 \\
-\end{array}$ & 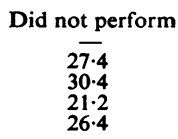 \\
\hline
\end{tabular}

Subjects A11 and A24 to A40 gave values within the normal limits in the initial survey.

*2 S.D.s from control mean.

results with the same test. This slight degree of glycosuria was consistently present in repeated specimens of urine. Two men at Factory B (Cases B2 and B4) were found to have $0.25 \%$ and $1 \%$ respectively of glucose in the urine. Both these men had typical mild diabetic glucose tolerance curves. Seven of the nine men exhibiting glycosuria in Factory A also had proteinuria and all 10 of the men at Factory B with glycosuria also had proteinuria.

The results of analysis of cadmium excretion in the urine are given in Tables 1 and 2. No correlation was found between the excretion of cadmium in 24-hour specimens and the excretion in spot specimens of urine.

Urinary cadmium excretion in the control group was not studied on this occasion. Bonnell (1955) gave data of a similar control group of 89 men, 76 of whom were not excreting detectable amounts of cadmium, 10 were excreting 10/30 $\mu \mathrm{g}$. of cadmium per day, and three were excreting over $30 \mu \mathrm{g}$. per day. On that occasion the polarographic technique used had a similar sensitivity, i.e., $10 \mu \mathrm{g}$. cadmium per litre of urine, to that used in the survey now reported. Smith and Kench (1957) found a similar distribution amongst the 28 subjects in their control group.

As in 1953 questioning did not reveal evidence of watery discharge from the nose or loss of the sense of smell. It was impossible to assess whether a 
yellow discoloration of the teeth was present owing to the poor oral hygiene in the majority of the workers. The blood pressure readings were not higher than in the control groups; in fact they were almost identical in individual workmen after a four-year interval. No cadmium was detected in the blood obtained by venepuncture.

\section{Discussion}

It is clear from the evidence obtained as the result of this investigation that the first sign of chronic cadmium poisoning can occur after a long latent interval following cessation of exposure to cadmium. When signs or symptoms of poisoning are present, the disease progresses in severity with time and this deterioration occurs in the absence of further exposure to cadmium.

It can be seen from Table 2 that six of the 10 new cases at Factory B had ceased to be exposed to cadmium by 1950 . One of these men had only been exposed for three years, from 1939 to 1942 . All were normal on examination during the survey carried out at this factory in 1953 (Bonnell, 1955). At Factory A four of the 14 new cases had their last exposure in 1953. Since working conditions were good in 1957, as evidenced by the environmental study, it is unlikely that any of the 24 new cases were due to absorption of cadmium in the period 1953 to 1957.

The men diagnosed as having chronic cadmium poisoning in 1953 showed evidence of deterioration. Three had died (Cases A4, A9, and B3), two as the result of respiratory disease and one of bronchogenic carcinoma. At Factory A only two of the known cases of chronic cadmium poisoning were still at work (Cases A7 and A8), and in one of these (Case A8) there was undoubted evidence of increased severity of the disease. One man (Case A6) who had emphysema only in 1953 had become completely disabled and for the first time had proteinuria. At Factory B only four of the 10 men known to have chronic cadmium poisoning continued at their usual work in the casting shop. Deterioration was demonstrated by clinical examination and respiratory function tests in the remaining six men. One was completely disabled, another was only capable of carrying out sedentary work, and four were only able to do light work.

The results of the respiratory function tests showed a deterioration with increase in age in the exposed groups compared with the control group.

A new group of involuntary controls was investigated at one of the factories; the results are comparable with those obtained in volunteer control groups in 1953, thus validating the original control series and verifying that the procedure adopted in
1957 did not vary significantly from that adopted in 1953.

The measurement of the time constant of the expiratory fast vital capacity curve gave unequivocal results. No difference could be demonstrated between the performance of the 1953 and 1957 control groups, as shown by the similarity of the regression equations on age in each group. However, there was a significant difference between the 1957 control group and the exposed groups in each factory. This difference is well illustrated in Fig. 1. The results for the M.V.C. ${ }_{70}$ and for the swept fraction support these findings. No useful conclusion could be drawn from the vital capacity results in this any more than in the initial survey. The expiratory fast vital capacity curve provided a reliable and sensitive index of ventilatory function.

The comparison between the exposed groups in 1953 and 1957 showed a greater deterioration than could be expected from the behaviour of the control groups studied. The deterioration over four years in the control group was calculated from observations made on a single occasion. The 1957 investigation was handicapped in this respect because the original control group was not available for examination.

In assessing the respiratory function of individuals, the results of these tests corresponded well with clinical and radiological findings. In a number of cases men who gave abnormal results on this survey gave readings which were close to the normal limits four years previously. It would be of interest to repeat these tests after a further period on men whose results were for the first time close to the normal limits.

The radiological findings agreed closely with the clinical findings and the results of the respiratory function tests. The chest radiographs were inspected without any knowledge of the clinical findings so that an unbiased opinion could be taken of each chest film.

All 10 new cases at Factory B and eight of the 14 new cases at Factory A had proteinuria only. It has been established that the proteinuria in the new cases is identical with that described by Kekwick (1955). Spectrophotometric examination of the urinary proteins gave extinction values at $280 \mathrm{~m} \mu$, in the range found for proteins, providing additional evidence that they are protein in nature. Estimation of the bound carbohydrate of these proteins by the method of Sørensen and Haugaard (1933) on three samples of the proteins gave the following values, $18.2 \%, 22.3 \%, 29.5 \%$. These figures indicate that these are mucoproteins with a high polysaccharide content and this is consistent with their reaction to sulphosalicylic acid (Kekwick, 1957). 
Proteinuria is a common finding in renal disease; in chronic glomerulonephritis, pyelonephritis, or the kidney of hypertension the proteins are plasma proteins with an excess of albumin. The protein in the urine of men suffering from cadmium poisoning is a specific protein which has a molecular weight of 20,000 to 30,000 . It is not clear therefore whether this protein is present in the urine as the result of renal damage or whether it has a sufficiently small molecule to pass through a normal kidney. Since, however, this proteinuria only occurs following absorption of cadmium it is evident that a toxic process has occurred. The only other naturally occurring disease in which a specific proteinuria occurs is multiple myeloma, when Bence-Jones protein is present in the urine of a certain proportion of cases. Patients suffering from multiple myeloma can die as the result of renal failure, the histological lesion being essentially one of primary tubular damage.

Clarkson and Kench (1956) studied the aminoacid content of the urine of men exposed to lead, mercury, uranium, and cadmium, the latter as cadmium oxide dust in the accumulator industry. They found that the cadmium and uranium workers had an increased amount of amino-acids in the urine and that this finding was more marked in the cadmium workers than in those exposed to uranium. It was particularly marked in those men who were excreting the specific cadmium protein. Aminoaciduria occurring in the absence of advanced hepatic failure is a manifestation of renal tubular damage, provided the plasma amino-acid levels are not increased. The plasma amino-acid levels in workers exposed to cadmium showing the aminoaciduria are not available.

During the survey described in this paper it was found that, using a sensitive qualitative test for glucose 19 of the 82 men had glycosuria. One of these had suffered from diabetes mellitus for many years; of the remaining 18 men, 17 were also excreting the cadmium protein in the urine. This observation has been confirmed independently by Kench and Smith (1957) during routine testing of the urine of workers exposed to cadmium oxide dust in the alkaline accumulator industry. These two findings are compatible with early renal tubular damage.

Of the cases studied in hospital, one man died in uraemia from chronic renal failure (Case A1, Bonnell, 1955) and granular contracted kidneys were found at necropsy. The histological changes were non-specific but in cases of advanced renal disease it is frequently impossible to find histological evidence incriminating any one aetiological factor. Abnormal renal function tests have been demonstrated in three other cases (A2, B1, and B6, Bonnell, 1955).
Severe renal damage can be produced in rats following repeated administration of small quantities of cadmium for periods of up to one year (Bonnell, King, and Ross, in preparation). The lesion is primarily one of tubular damage, the glomeruli remaining intact. In these experiments it was shown that if the administration of cadmium was stopped after four to five months, when only a slight degree of renal damage had been produced, the kidneys of these animals were as severely affected at the conclusion of the experiment as those of the animals which had received the cadmium for 12 months. Tubular necrosis has also been produced in rabbits by Dalhamn and Friberg (1957) after daily subcutaneous injections of cadmium for 10 weeks. Knowledge will not be complete until further human cases have been studied at necropsy, but the evidence available at present suggests that progressive renal damage does occur following prolonged absorption of cadmium.

There is some evidence that the urinary excretion of cadmium may be affected by the general health of the patient. In one instance (Case B6) the cadmium content in the urine rose from $24 \mu \mathrm{g}$. per day to $440 \mu \mathrm{g}$. per day coinciding with an acute illness, in this case a spontaneous pneumothorax. In another case (A2) cadmium excretion reached a figure of $900 \mu \mathrm{g}$. per day during acute bronchopneumonia but when last examined this patient was excreting $25 \mu \mathrm{g}$. cadmium per litre of urine. Case B3 when seen in 1953 was excreting $1.24 \mathrm{mg}$. of cadmium per day in the urine. At post-mortem examination on this patient (Smith, Kench, and Smith, 1957) the bile contained $24 \mu \mathrm{g}$. of cadmium per g. representing an excretion of about $19 \mathrm{mg}$. of cadmium per day. The liver contained $160 \mu \mathrm{g}$. of cadmium per $\mathrm{g}$. and at this rate of excretion all the cadmium would have been removed from the liver in three to four months. High concentrations of cadmium were also present in the aorta and main vessels in this case. This man died of acute bronchopneumonia and it could well be that cadmium was released from the tissues during this acute illness.

The analysis of the cadmium concentration of the atmosphere in both factories suggested that provided individual workmen took great care, there was probably little hazard at that time. Despite this, the measurement of cadmium on face masks worn for a single operation by men employed at Factory B showed that even under those conditions large amounts of cadmium could have been absorbed by a careless workman and suggested that the ventilation system could be improved further.

Of the 100 men first examined in 1953 at these two factories, 43 are now known to have symptoms or signs of the disease. In addition, seven other cases 
are known among ex-employees. The disease is chronic and in the majority of cases patients may succumb to anoxia due to emphysema or to some intercurrent pulmonary infection before the renal lesion has had time to develop. The new cases described in this paper have in many instances no evidence of pulmonary involvement, so that in them the renal lesion may become the more important feature of the disease.

We are indebted to the medical and personnel departments of the two factories concerned for their continued assistance and wholehearted cooperation; to Dr. Donald Hunter and Dr. P. L. Bidstrup for their advice and encouragement; to Dr. R. A. Kekwick for advice and assistance in protein identification; to Dr. Richard Doll for his advice on the planning of the survey; and to Miss J. Peal and Mr. B. Biles for technical assistance. We should also like to thank Dr. E. H. Evison for consultations over Cases D1 and D2, and Dr. G. L. Manson who arranged for glucose tolerance tests in Cases B3 and B4 and renal function tests in Case B6.

\section{REFERENCES}

Armitage, P. (1955). Personal communication.

Bernstein, L., D'Silva, J. L., and Mendel, D. (1952). Thorax, 7, 255. Bonnell. J. A. (1955), Brit. J. industr. Med., 12, 181.

, King, E., and Ross, J. H. In preparation.

Clarkson, T. W., and Kench, J. E. (1956). Biochem. J., 62, 361.

Dalhamn, T. and Friberg, L. (1957). Acta. path microbiol. scand., 40,475 .

D'Silva, J. L., Freeland, D. E., and Kazantzis, G. (1953). Thorax, 8, 303.

, and Kazantzis, G. (1954). Ibid., 9, 128.

Friberg, L. (1950). Acta med. scand., Suppl. 240.

Gandevia, B., and Hugh-Jones, P. (1957). Thorax, 12, 290.

Kazantzis, G. (1956). Brit. J. industr. Med., 13, 30.

Kekwick, R. A. (1955). Ibid., 12, 196.

(1957). Personal communication.

Kench, J. E. and Smith, J. C. (1957). Personal communication.

King. E. (1955). Brit. J. industr. Med., 12, 198.

Smith. J. C., and Kench, J. E. (1957). Ibid., 14, 240.

-, and Smith, J. P. (1957). Ibid., 14, 246.

Sørensen, M., and Haugaard, G. (1933). C.R. Lab. Carlsberg 19 No. 12 .

Wright, B. M. (1954). Brit. J. industr. Med., 11, 284.

\section{A P P E N D I X 1}

\section{Follow-up Notes of Cases Previously Reported}

Factory A.-The following cases were investigated from Factory A.

Case A5.-A man, aged 62, had cast copper-cadmium alloys from 1938 to 1950 . He continued to work in the casting shop until March, 1954, when he was forced to retire because of the severity of his symptoms. He was extremely short of breath, but complained of no cough and little sputum; on clinical examination there was evidence of severe emphysema with bronchospasm. The blood pressure was $160 / 110 \mathrm{~mm} . \mathrm{Hg}$ and the urine contained protein. The respiratory function tests were grossly abnormal (Table 8).

Case A7.-A man, aged 60, had continued to work in the casting shop but had not actually cast coppercadmium alloys since August, 1956. He was symptomfree; on clinical examination blood pressure was 120/80 $\mathrm{mm}$. $\mathrm{Hg}$, no emphysema was demonstrable, but the liver was enlarged and palpable three fingerbreadths below the right costal margin. The urine contained the characteristic protein and traces of cadmium (10 to 15 $\mu \mathrm{g}$. per litre). Glycosuria was demonstrable. Respiratory function tests showed no deterioration since 1953 and the chest radiograph was normal.

Case A8.-A man, aged 59, had cast copper-cadmium alloys from 1921 to 1943 and since that time he had worked on the manufacture of copper wire. His symptoms were more severe and he was constantly short of breath aggravated each winter by cough and sputum. On clinical examination there was evidence of severe emphysema, blood pressure was $130 / 90 \mathrm{~mm}$. $\mathrm{Hg}$, and the urine contained the characteristic protein. A mid-day sample of urine contained $70 \mu \mathrm{g}$. of cadmium per litre and the test for glucose was positive. There was radiological evidence of increased severity of the emphysema compared with 1953; the range of diaphragmatic move- ment was reduced and there was an increase of the reticular pattern of the lungs with bullous areas at both apices and at the right base. The respiratory function tests were grossly abnormal (Table 8).

Case A11.-A man. aged 69, had worked for 20 years in the vicinity of the copper-cadmium furnaces. In 1953 there was clinical evidence of chronic bronchitis and emphysema but respiratory function tests and a chest radiograph were normal. Proteinuria was demonstrable. In March, 1955, he had a cardiac infarction and was forced to retire from work. He was very short of breath and also suffered from a cough, sputum, and angina of effort. On clinical examination there was evidence of emphysema and chronic bronchitis but in addition there were signs of left ventricular failure with cardiac enlargement, ventricular extrasystoles, and a blood pressure of $160 / 100 \mathrm{~mm}$. $\mathrm{Hg}$ with pulsus alternans. The characteristic protein was present in the urine and respiratory function tests were grossly abnormal (Table 8) confirming a diagnosis of emphysema. The urine contained $10 \mu \mathrm{g}$. of cadmium per litre.

Case A12.-A man, aged 58, had worked in the vicinity of the copper-cadmium furnaces from 1935 to 1945. He had retired from work in 1953 because of the severity of his symptoms. He complained of severe shortness of breath with "tightness" of the chest but no cough or sputum. There was clinical evidence of severe emphysema with bronchospasm, and the urine contained the characteristic protein but no cadmium was detected. The respiratory function tests (Table 8) confirmed deterioration.

Factory B.-The following cases were seen at Factory B.

Case B1.-A man, aged 56, had cast copper-cadmium alloy from 1930 to 1950 . In December 1956, he complained of a sudden severe pain over the left lower part 
of the chest which was accompanied by extreme dyspnoea. He had been extremely dyspnoeic since that time. On clinical examination there was evidence of advanced emphysema with bullae at both lung bases. The chest radiograph confirmed this. It is probable that he suffered a spontaneous pneumothorax in December, 1956. The respiratory function tests were grossly abnormal (Table 8). Protein was present in the urine, which also contained $25 \mu \mathrm{g}$. of cadmium per litre.

Case B2.-A man, aged 53, had continued to supervise the casting shop. He complained of dyspnoea on effort and winter cough; emphysema was demonstrable clinically and radiologically and the respiratory function tests were abnormal (Table 8). Proteinuria and glycosuria were demonstrated. Glucose tolerance tests showed the typical response of mild diabetes mellitus. He was excreting $20 \mu \mathrm{g}$. of cadmium per litre of urine.

Case B4.-A man, aged 61, had not been exposed to cadmium after 1953. Dyspnoea was more severe than at the time of the previous examination; a marked degree of emphysema accompanied by bronchospasm was evident on clinical examination. The respiratory function tests confirmed the clinical impression of deterioration (Table 8). Proteinuria and glycosuria were demonstrated. On further investigation he was shown to have a diabetic glucose tolerance curve. No cadmium was detected in the urine.

Case B5.-A man, aged 63, had not been exposed to cadmium after 1947. Shortness of breath was as severe as at the first examination, but he had not complained of cough. The chest radiograph and respiratory function tests confirmed the diagnosis of emphysema and the respiratory function tests (Table 8) showed that the emphysema was more severe. Proteinuria was present and also traces of cadmium in the urine.

Case B6.-A man, aged 54, was exposed to cadmium for seven years from 1945 to 1952 . On examination in 1953 he was found to have emphysema and bronchospasm; the liver and spleen were palpable on examination of the abdomen. He remained reasonably well until August, 1956, when he was admitted to hospital because of a sudden exacerbation of dyspnoea accompanied by severe chest pain. On admission he was found to have a left-sided pneumothorax with collapse of approximately $30 \%$ of the lung. He made an uneventful recovery with symptomatic treatment. No protein was demonstrable in the urine but excretion and concentration tests of the urine showed slight impairment of renal function. On examination respiratory function tests showed marked deterioration in four years (Table 8). The chest radiograph showed an increase in size of the hilar vessels and of the transverse diameter of the heart compared with the film taken in 1953.

The daily urinary excretion of cadmium in this man was $24 \mu \mathrm{g}$. in 1953. During his illness in August and September, 1956, this figure rose to $440 \mu \mathrm{g}$. During convalescence at home, but before returning to work, the daily excretion was $153 \mu \mathrm{g}$. In June, 1957, by which time he had completely recovered from the acute effects of the pneumothorax and was back at work, the daily excretion was again low, namely $34 \mu \mathrm{g}$. of cadmium per day.
Case B7.-A man, aged 41, was symptom-free, but proteinuria and glycosuria were present on testing repeated samples of urine. The urine contained no cadmium.

Case B8.-A man, aged 40, complained of some dyspnoea on exertion but no abnormality was detected on examination. Proteinuria was again marked and glycosuria was also demonstrable. No cadmium was detected in the urine.

Case B9.-A man, aged 65, no longer worked in the casting shop and was semi-retired. He was symptomfree but proteinuria and glycosuria were present in repeated specimens of urine, which also contained $25 \mu \mathrm{g}$. of cadmium per litre.

Case B10.-A man, aged 45, complained of some dyspnoea on effort, but no emphysema was demonstrable on examination. Proteinuria was demonstrated but no glycosuria. The urine contained $24 \mu \mathrm{g}$. of cadmium per litre.

New Cases.-These cases have been seen since the report of the previous investigation.

Case D1.-A man, aged 51 years, in whom a diagnosis of emphysema with bronchospasm was made. The characteristic protein was present in the urine. He had worked from 1933 to 1939 casting copper-cadmium alloys at Factory A. He served in the armed forces from 1939 to 1942 when he was discharged to carry out essential industrial work; he continued casting coppercadmium alloys from 1942 to 1945 . Since 1945 he had worked as a bus conductor.

He was quite well until 1945 when he first became short of breath on exertion with "tightness" of the chest and a slight unproductive cough. The dyspnoea gradually increased in severity and had become severe since 1951 following an acute attack of bronchitis. Dyspnoea had been constant since 1954 .

On examination in May, 1957, there was a slight degree of cyanosis but no finger clubbing. The chest was fixed in inspiration. There was complete absence of cardiac and liver dullness on percussion and the heart sounds were best heard over the xiphisternum. The chest was hyperresonant on percussion, breath sounds were vesicular, and many high-pitched rhonchi were heard. The urine contained the characteristic protein and $12 \mu \mathrm{g}$. of cadmium per litre.

Case D2.-This was a man aged 63 years who had proteinuria only. He had worked from 1939 to 1956 in the casting shop at Factory A casting brass, bronze, and copper-cadmium alloys. He had refused to take part in the survey in 1953, but did provide an early morning specimen of urine which at that time was normal.

For 12 months he had complained of dyspnoea on exertion with cough and sputum for nine to 10 months. On examination in May, 1957, he was not cyanosed and the fingers were not clubbed. Chest expansion was $1 \frac{1}{2}$ inches. Cardiac and liver dullness were within normal limits on percussion of the chest. The breath sounds were vesicular, air entry was good at both the apices and bases of the lungs, and occasional rhonchi, dispersed by coughing, were heard. There was no evidence of emphysema.

The characteristic protein was present in the urine, which contained $10 \mu \mathrm{g}$. of cadmium per litre. 


\section{A P P E N D I X 2}

Dust respirators should not be used as the primary protection against dusts or fume, but only as additional safeguards when the nature of the work does not allow adequate exhaust ventilation covering the source of emission at all times. During the manufacture of coppercadmium alloys the workmen are required to be close to the source of cadmium oxide fume and respirator protection at these times would reduce their exposure to the fume.

The effective use of respirators requires that they should be efficient against the type of material concerned; that they should be sufficiently comfortable under conditions of temperature and exertion so as not to reduce the efficiency of the workmen; and that supervision is available to ensure their use at the appropriate times. These conditions appeared to be satisfied in Factory B by the Siebe Gorman "microfilter" dust respirators. In order to obtain data on their efficiency in the working conditions observed against cadmium oxide fume two respirators were obtained after their use by two workmen during a series of mixing and casting operations.
The wadding filters of the respirators were each divided into six approximately equal sections from front to rear of the mask, and analysis for cadmium content was performed on each section. In order to avoid errors arising from sparks trapped in the first sections, the data plotted in Fig. 3 give the amount in any one section of each mask as a percentage of the total amount in that section and those to the rear of it. Thus the higher apparent efficiencies of the first two sections were possibly caused by the presence of large particles, but the next three each showed an efficiency of about $50 \%$ which may be assumed to be against the residual fume after the removal of particles formed by sparks.

The data obtained thus showed that each section of the filters contained about $50 \%$ of the cadmium oxide fume entering it. The overall efficiency is therefore that of six sections in series, each of $50 \%$ efficiency, to give a very high overall efficiency. These respirators can therefore be accepted as suitable protective devices to be used in addition to exhaust ventilation covering the sources of the cadmium oxide fume.

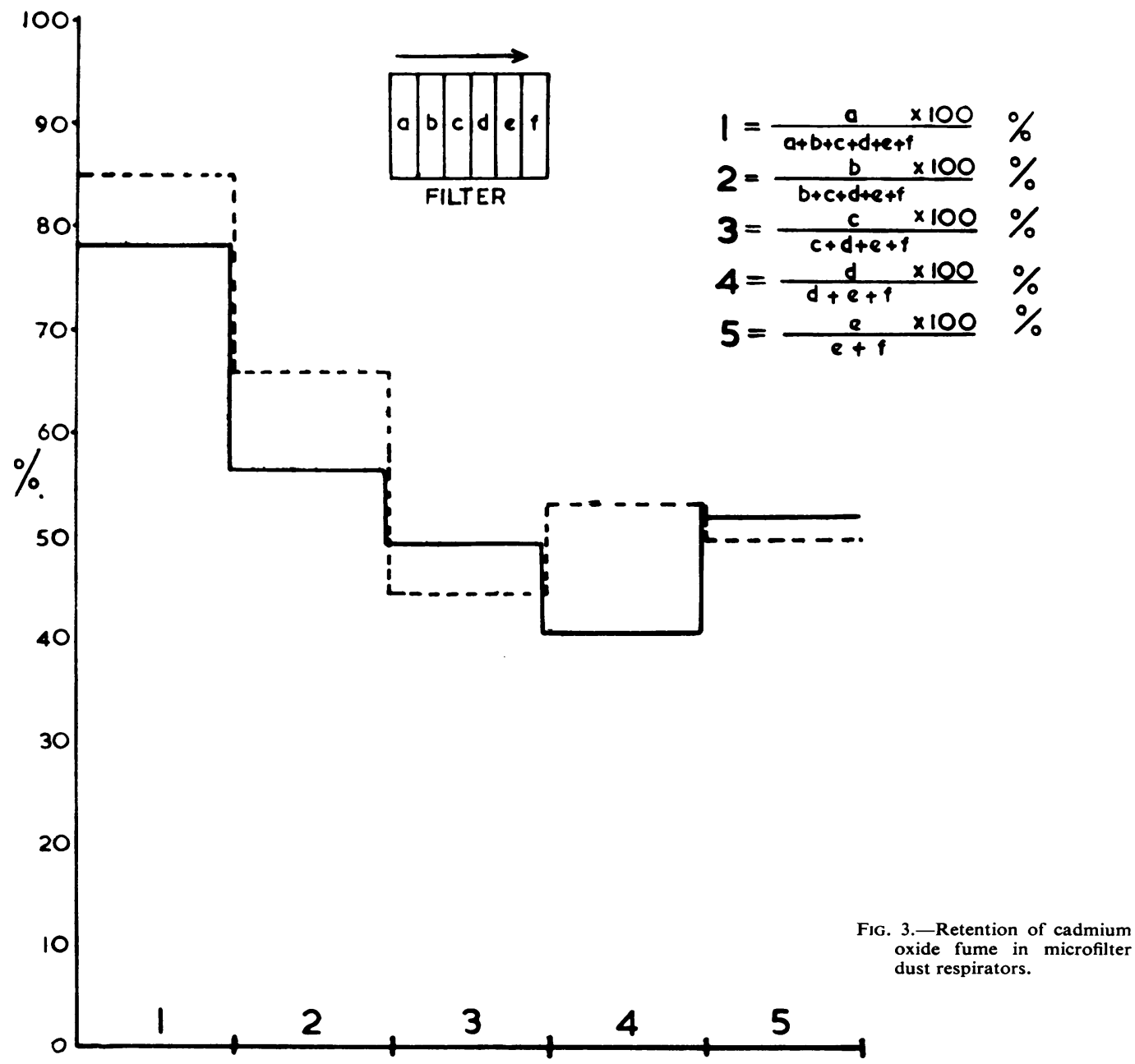

